\title{
Respon Fisiologis dan Lama Pemulihan pada Kambing Kejobong Jantan Muda dan Dewasa Akibat Transportasi
}

\section{(The Physiological Responses And Recovery Time in Adult and Young Kejobong Goats After Transportation)}

\author{
Wilasari BA, Rianto E, Mawati S \\ Fakultas Peternakan dan Pertanian, Universitas Diponegoro, Semarang \\ JL. Prof. h. Soedarto, S.H. - Tembalang, Semarang, Indonesia 50275 \\ erianto_05@yahoo.com
}

\begin{abstract}
This study was aimed to assess the physiological responses and recovery time of adult and young Kejobong goats after transportation. A total of eight heads of Kejobong goats $(\mathrm{n}=$ 8 ; initial body weight $(\mathrm{BW}) 12.49 \pm 1.08 \mathrm{~kg}$ ) and eight young goats $(\mathrm{n}=8 ; 18.21 \pm 1.70 \mathrm{~kg})$ were used in this study. The data was analyzed by independent sample comparison in two groups of ages The goats was transported from Purbalingga to Semarang (distance of 160 $\mathrm{km})$. Before, during and after the transportation process, observations were on the physiological conditions, including pulse and respiratory rates, and rectal temperature. The results showed that heart and respiratory rates in goats (98 times a minute and 37 times a minute) were higher than the younger ( 89 times a minute and 27 times a minute), while young goats had higher rectal temperature after 10 hours transportation $\left(39,2^{\circ} \mathrm{C}\right.$ vs $\left.39,0^{\circ} \mathrm{C}\right)$. It was concluded that heart and respiratory rates in goats were higher during the transportation, while young goats had lower rates after the transportation. Goats had shorter time of recovery than kids.
\end{abstract}

Key words: Adult and young, goats, transportation, recovery time, physiological responses

\begin{abstract}
ABSTRAK
Penelitian ini bertujuan untuk menilai perubahan kondisi fisiologis dan lama pemulihan kambing Kejobong muda dan dewasa akibat transportasi. Materi yang digunakan dalam penelitian ini adalah 8 ekor kambing Kejobong muda (4 bulan, bobot badan 12,49 $\pm 1,08 \mathrm{~kg}$ ) dan 8 kambing Kejobong dewasa ( 8 bulan, bobot badan 18,21 $\pm 1,70 \mathrm{~kg}$ ). Penelitian ini menggunakan metode Independent Sample Comparison, yaitu membandingkan 2 kelompok umur kambing Kejobong jantan dan di uji secara deskriptif. Kambing tersebut diangkut dari Purbalingga ke Semarang (jarak $160 \mathrm{~km}$ ). Sebelum, selama dan setelah proses transportasi, dilakukan pengamatan terhadap kondisi fisiologis kambing, meliputi denyut nadi, frekuensi nafas dan suhu rektal. Hasil penelitian menunjukkan bahwa frekuensi denyut nadi dan nafas pada kambing dewasa (98 kali/menit dan $37 \mathrm{kali} /$ menit) lebih tinggi daripada kambing muda (89 kali/menit dan $27 \mathrm{kali} /$ menit), sedangkan kambing muda memiliki suhu rektal lebih tinggi setelah 10 jam transportasi $\left(39,2{ }^{\circ} \mathrm{C}\right.$ vs $\left.39,0{ }^{\circ} \mathrm{C}\right)$. Disimpulkan bahwa denyut nadi dan nafas kambing dewasa mengalami peningkatan selama transportasi, sedangkan suhu rektal kambing muda mengalami penurunan akibat dari transportasi. Waktu pemulihan kambing dewasa lebih pendek daripada kambing muda.
\end{abstract}

Kata kunci: Kambing muda dan dewasa, transportasi, lama pemulihan, respon fisiologis 


\section{PENDAHULUAN}

Kambing Kejobong merupakan hasil persilangan dari kambing India (Ettawa/Benggala) dengan kambing Kacang yang kemudian diseleksi terhadap warna hitam oleh peternak di Kecamatan Kejobong, Kabupaten Purbalingga (Pramono et al. 2005). Dominasi warna ternak yang berhubungan dengan seleksi merupakan faktor kesenangan terhadap salah satu warna, peternak senang dengan kambing yang memiliki warna hitam diseluruh tubuhnya (Sodiq 2009). Banyaknya minat peternak di luar daerah Purbalingga terhadap kambing kejobong yang mengharuskan peternak di daerah Purbalingga melakukan proses pengiriman ternak antar kota. Peran penting dalam usaha peternakan terutama untuk proses pengiriman dan pemasaran adalah transportasi.

Transportasi merupakan suatu faktor penunjang dalam manajemen perusahaan peternakan untuk melakukan distribusi ternak ke konsumen. Proses dalam transportasi dapat mencakup dalam satu daerah, antar kota dan antar pulau. Ternak yang ada di dalam mobil pengangkut dimuat dengan posisi berdiri dan jarak yang rapat antar ternak lainnya. Kondisi tersebut dapat menyebabkan luka, penyusutan bobot badan, stres pada ternak dan terjadi perubahaan status fisiologisnya (Lasmi 1988). Penyusutan yang terjadi dipengaruhi oleh keringat, lamanya pengangkutan ternak, kondisi jalan yang ditempuh, suhu udara, umur ternak, dan feses dan urin yang keluarkan (Setyawan 2013). Stres yang diakibatkan dari transportasi berlangsung lama dan akan menimbulkan peningkatan tekanan darah, denyut jantung, intake oksigen dan gangguan pencernaan (Karnadi 1999).

Pasca transportasi juga akan mempengaruhi produktivitas ternak, sehingga ternak harus melalui proses adaptasi lingkungan dan pemulihan baik pemulihan fisiologis ternak, konsumsi pakan dan bobot badan (Ramadhan et al. 2017). Pemulihan terhadap konsumsi pakan pada ternak kambing setelah mengalami perpindahan tempat pemeliharaan memerlukan waktu sekitar 5 - 7 hari dan lama pemulihan pada ternak tergantung dari jenis ternak dan kemampuan dalam beradaptasi (Santosa et al. 2012). Faktor yang mempengaruhi pemulihan konsumsi dan fisiologis yaitu umur ternak yang berbeda. Umur ternak yang lebih dewasa akan lebih cepat mengalami pemulihan konsumsi dan kondisi fisiologis, jika dibandingkan dengan ternak yang umurnya masih muda.

Penelitian ini bertujuan untuk menilai perubahan kondisi fisiologis ternak (suhu rektal, frekuensi nafas dan denyut nadi) dan pemulihan ternak akibat transportasi pada kambing Kejobong muda dan dewasa. Manfaat dari penelitian ini adalah mendapatkan informasi kondisi fisiologis ternak dengan umur yang berbeda dan waktu lama pemulihan akibat transportasi.

\section{MATERI DAN METODE}

Penelitian ini dilaksanakan di tiga tempat yaitu Purbalingga, selama transportasi dari Purbalingga menuju Semarang dan masa pemulihan serta pemeliharaan dilakukan di kandang laboratorium Nutrisi Ruminansia, Universitas Diponegoro, Semarang pada bulan September 2018.

\section{Materi}

Pada studi ini digunakan adalah 16 ekor kambing Kejobong jantan, terdiri atas 8 ekor kambing muda (4 bulan, bobot badan 12,49 $\pm 1,08 \mathrm{~kg}$ ) dan 8 ekor kambing dewasa ( 8 bulan, bobot badan $18,21 \pm 1,70 \mathrm{~kg}$ ). Bahan pakan yang digunakan berupa rumput 
Brachiaria mutica. Peralatan yang digunakan untuk pengambilan data meliputi stetoskop merk onemed ${ }^{\circledR}$ untuk mengukur denyut jantung, termometer klinis tipe digital merk omron ${ }^{\circledR}$ untuk mengukur suhu rektal, handcounter, stopwatch serta timbangan tipe digital merk $S F-400 ®$ untuk menimbang pemberian dan sisa pakan.

\section{Metode}

Kambing percobaan diangkut dari Kecamatan Kejobong, Kabupaten Purbalingga ke Fakultas Peternakan dan Pertanian, Universitas Diponegoro, Semarang. Proses transportasi dimulai pada pukul 12.53 WIB. Sebelum kambing kejobong ditransportasikan dilakukan pengukuran fisiologis ternak, setelah itu ternak diangkut dengan menggunakan mobil pickup. Ternak kambing pada saat ditransportasikan menuju Semarang ada salah satu orang berada di belakang bak pickup untuk menjaga dan mengawasi ternak. Selama transportasi dilakukan pemberhentian dua kali, pada saat berhenti fisiologis kambing diukur dan diberi air minum. Setelah tiba di tempat tujuan, pengukuran fisiologis kambing dilakukan kembali dan hewan dipelihara hingga kambing pulih.

Hasil dari penelitian ini dianalisis menggunakan Independent Sample Comparison menurut Steel and Torrie (1993), yaitu membandingkan 2 kelompok kambing Kejobong dengan umur berbeda, yaitu umur muda $(\mathrm{T} 1)=4$ bulan dan dewasa $(\mathrm{T} 2)=8$ bulan. Data yang diambil meliputi data fisiologis ternak meliputi denyut nadi, frekuensi nafas serta suhu rektal, konsumsi pakan dan minum, data kondisi lingkungan meliputi suhu dan kelembaban dan bobot badan. Pengambilan data fisiologis ternak dilakukan 3 kali. Pertama, data awal di lokasi peternakan yaitu di Purbalingga. Kedua, data selama perjalanan dengan pemberhentian dua kali dengan jarak yang berbeda. Ketiga, data setelah sampai di kandang Fakultas Peternakan dan Pertanian Undip.

Pengukuran denyut nadi dilakukan dengan pengamatan denyut yang terdengar dari stetoskop yang diletakkan di bagian dada atau bawah kiri dari badan kambing, pengukuran frekuensi nafas dilakukan dengan pengamatan bagian perut dan dada kambing Kejobong, sedangkan pengukuran suhu tubuh dilakukan dengan termometer klinis yang diletakan pada rektum kambing Kejobong. Seluruh pengukuran data fisiologis ternak dilakukan selama 2x1 menit dengan perhitungan waktu menggunakan stopwatch.

\section{HASIL DAN PEMBAHASAN}

\section{Pengaruh transportasi terhadap frekuensi denyut nadi dan lama pemulihan}

Frekuensi denyut nadi sebelum transportasi, selama transportasi dan setelah transportasi pada kambing Kejobong muda dan dewasa dapat dilihat pada. Gambar 1 . Frekuensi denyut nadi pada kambing Kejobong dewasa adalah 98 kali/menit lebih tinggi daripada kambing muda yaitu $89 \mathrm{kali} /$ menit setelah transportasi. Frekuensi denyut nadi pada kambing Kejobong jantan dewasa lebih tinggi dari batas normal. Suwignyo et al. (2016) menyatakan bahwa kisaran normal denyut nadi ternak kambing adalah sekitar 76 $90 \mathrm{kali} / \mathrm{menit}$. Hal ini disebabkan karena kambing dewasa sedang berupaya untuk menjaga keseimbangan panas dalam tubuhnya. Isroli et al. (2004) menyatakan bahwa peningkatan yang terjadi pada denyut nadi merupakan suatu upaya ternak menjaga keseimbangan panas yang dilakukan dengan cara mengalirkan darah ke tepi kulit. Selye (1976) menyatakan bahwa peningkatan denyut nadi dan nafas terjadi saat ternak mendapatkan cekaman panas yang kemudian panas yang diterima melalui kulit dialirkan 
oleh darah perifer dan gastrointestinal menuju otak. Selanjutnya otak merespon dengan cara meningkatkan hormon kortisol untuk membantu tubuh meningkatkan suplai energi untuk keperluan adaptasi, epinefrin dan nofepineprin teraktifasi sehingga meningkatkan denyut nadi. Aktifitas hormonal tersebut menyiapkan ternak dalam menghindari dari cekaman panas yang diperoleh.

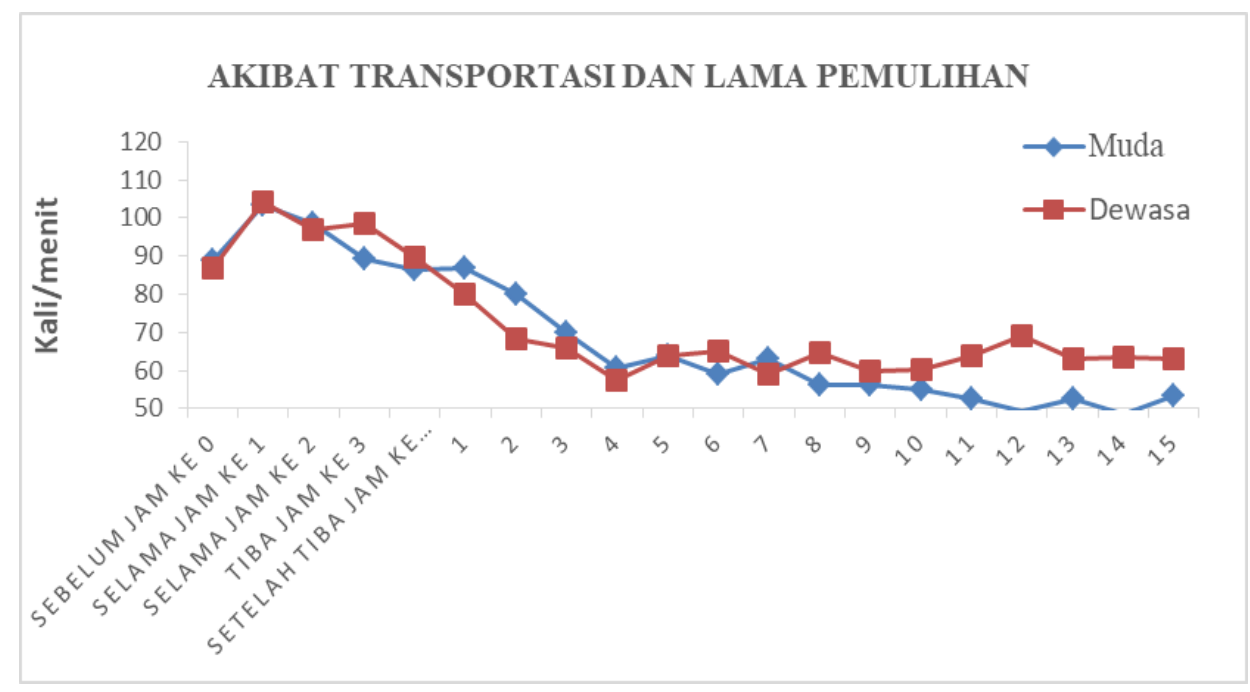

Gambar 1.Frekuensi denyut nadi sebelum transportasi, selama transportasi, setelah transportasi dan lama pemulihan

Frekuensi denyut nadi selama masa pemulihan pada kambing Kejobong muda dan dewasa dapat dilihat pada Gambar 1. Kambing Kejobong muda dan dewasa saat masa pemulihan membutuhkan waktu selama 14 hari, lamanya waktu untuk pulih disebabkan karena ternak sedang beradaptasi dengan kondisi lingkungan dan pakan yang baru setelah terjadi transportasi. Ramadhan et al. (2017) menyatakan bahwa waktu pulih yang dibutuhkan untuk kambing kacang muda dan dewasa yaitu sekitar 2 - 6 hari setelah ditransportasikan.

\section{Pengaruh transportasi terhadap frekuensi nafas dan lama pemulihan}

Frekuensi nafas sebelum transportasi, selama transportasi dan setelah transportasi pada kambing Kejobong muda dan dewasa dapat dilihat pada Gambar 2. Frekuensi nafas kambing Kejobong dewasa lebih tinggi yaitu 37 kali/ menit dibanding dengan kambing muda adalah $27 \mathrm{kali} /$ menit setelah transportasi. Frekuensi nafas kambing Kejobong jantan dewasa masih diatas batas nornal. Suwignyo et al. (2016) menyatakan bahwa kisaran normal frekuensi nafas ternak kambing adalah sekitar 26 - 36 kali/menit. Tingginya frekuensi nafas pada ternak merupakan proses termoregulasi untuk upaya membuang panas melalui udara. Semakin cepat frekuensi nafas dilakukan maka semakin cepat panas dalam tubuh sedikit. Wuryanto et al. (2010) bahwa laju metabolisme akan menyebabkan panas didalam tubuh meningkat yang dapat memicu proses termoregulasi, upaya yang dilakukan ternak ketika mengalami peningkatan frekuensi nafas yaitu ternak akan membuang panas melalui udara. 


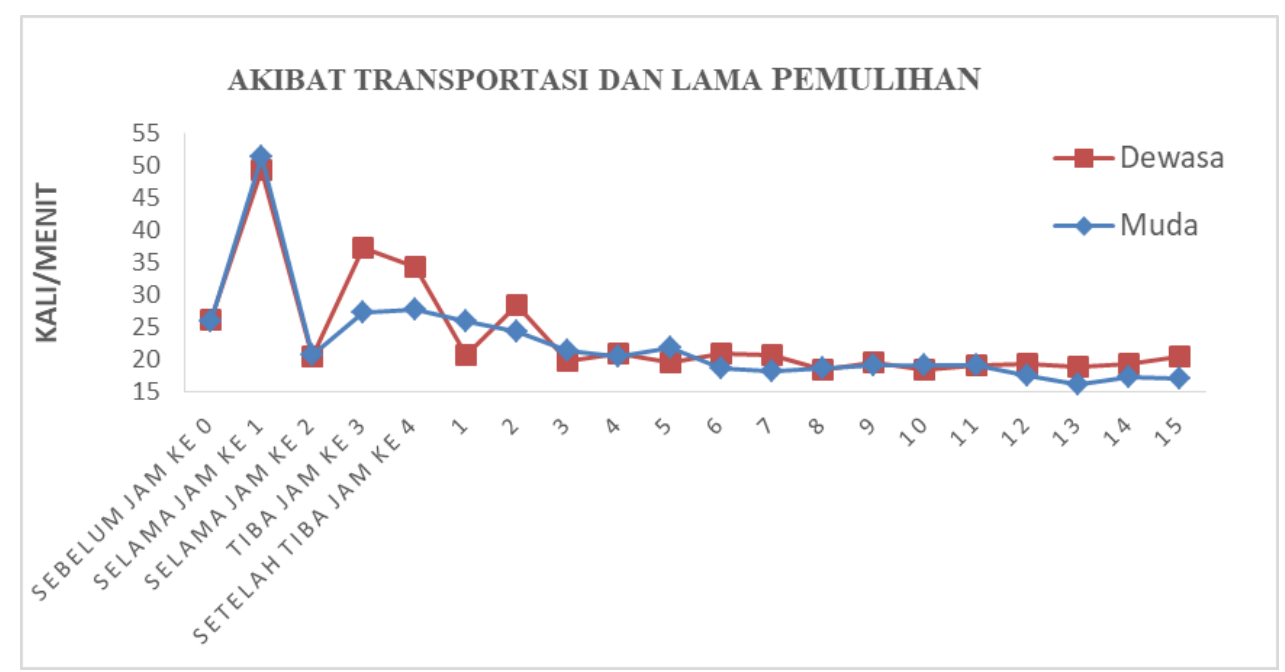

Gambar 2.Frekuensi nafas sebelum transportasi, selama transportasi, setelah transportasi dan lama pemulihan

Frekuensi nafas selama masa pemulihan pada kambing Kejobong muda dan dewasa dapat dilihat pada Gambar 2. Frekuensi nafas pada kambing Kejobong jantan dewasa bisa cepat pulih dan tidak membutuhkan waktu yang lama daripada kambing muda. Ramadhan et al. (2017) bahwa waktu pemulihan yang dibutuhkan kambing kacang dewasa $1-6$ hari dan muda $2-6$ hari. Kemampuan ternak saat beradaptasi terhadap suhu dan kelembaban lingkungan yang baru merupakan cara ternak untuk memulihkan kondisi fisiologisnya walaupun membutuhkan waktu yang lama untuk pulih. Puspitasari (2015) menyatakan bahwa waktu lama pemulihan kondisi fisiologis ternak pasca setelah mengalami transportasi dipenagruhi dari kemampuan adaptasi terhadap kondisi fisiologis lingkungan yang baru yaitu suhu dan kelembaban.

\section{Pengaruh transportasi terhadap suhu rektal dan lama pemulihan}

Suhu rektal sebelum transportasi, selama transportasi dan setelah transportasi pada kambing Kejobong muda dan dewasa dapat dilihat pada Gambar 3. Kambing Kejobong muda dan dewasa pada suhu rektal mengalami penurunan dari sebelum transportasi hingga selama transportasi pada jam 20.04 dan mengalami stabil selama transportasi di jam 20.04 hingga setelah transportasi pada jam 23.05. Suhu rektal pada kambing muda lebih tinggi adalah $39,2^{\circ} \mathrm{C}$ daripada kambing dewasa adalah $39,0^{\circ} \mathrm{C}$ setelah transportasi. Suhu rektal kambing muda dan dewasa masih dalam batas normalnya. Suwignyo et al. (2016) menyatakan bahwa kisaran normal suhu rektal ternak kambing adalah sekitar $38,6^{\circ} \mathrm{C}$ hingga $40,2^{\circ} \mathrm{C}$. Kambing muda belum bisa menyeimbangkan saat panas yang diterima dan dikeluarkan oleh tubuh setelah transportasi. Nelvita et al. (2018) menyatakan bahwa suhu tubuh selama transportasi masih berkisaran batas normal, menunjukkan adanya keseimbangan dari panas yang dilakukan domba untuk menerima dan mengeluarkan dari tubuh mendapat respon yang baik. Faktor yang dapat mempengaruhi tingginya suhu rektal adalah kondisi lingkungan yang berbeda dan stres perjalanan. Suherman et al. (2013) bahwa perubahan suhu udara, kelembaban udara, pergerakan angin dan radiasi matahari merupakan faktor yang dapat mempengaruhi kondisi fisiologis ternak. 
Suhu rektal selama masa pemulihan pada kambing Kejobong muda dan dewasa dapat dilihat pada Gambar 3. Kambing Kejobong muda dan dewasa pada suhu rektal selama masa pemulihan membutuhkan waktu 14 hari, suhu rektal kambing dewasa lebih tinggi daripada kambing muda. Waktu pulih kambig muda lebih cepat yaitu pada hari ke 11 sedangkan dewasa pada hari ke 12. Cepatnya kambing muda dapat pulih karena disebabkan adanyan suhu lingkungan yang lebih rendah dari pada suhu tubuh ternak. Ramadhan et al. (2017) menyatakan bahwa kondisi lingkungan yang berada di bawah dari suhu tubuh akan menyebabkan panas didalam tubuh akan cepat hilang. Faktor yang mempengaruhi waktu pemulihan lebih lambat adalah aktivitas ternak dan tergantung dari sifat khusus ternak. Pambudi (2017) menyatakan bahwa keberhasilan ternak dalam menyeimbangkan untuk melepas panas merupakan indikator dari suhu rektal. Panas tubuh yang diukur melalui suhu rektal tergantung dari sifat khusus ternak maupun lingkungan dan aktivitas yang dilakukan ternak.

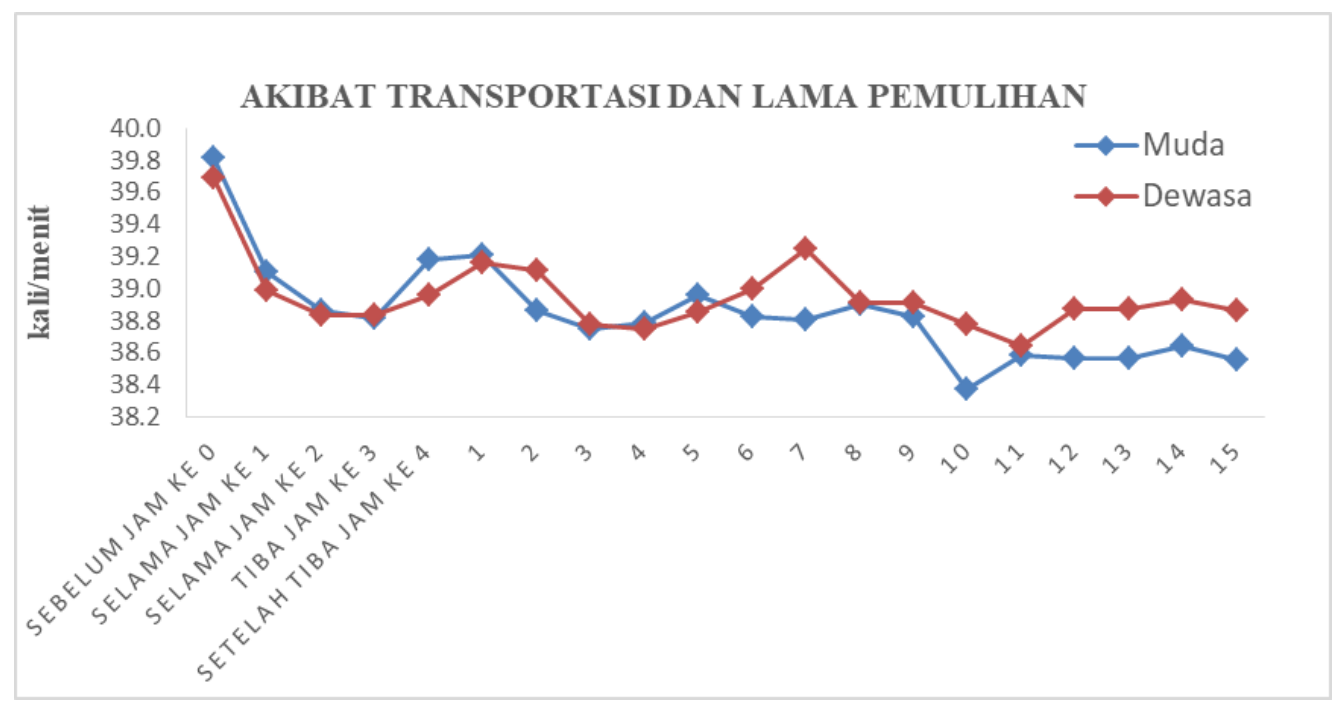

Gambar 3. Suhu rektal sebelum transportasi, selama transportasi, setelah transportasi dan lama pemulihan

\section{KESIMPULAN}

Dari hasil penelitian inidapat disimpulkan bahwa frekuensi denyut nadi dan nafas pada kambing dewasa mengalami peningkatan akibat dari transportasi, sedangkan suhu rektal kambing muda mengalami penurunan akibat dari transportasi. Waktu pemulihan kambing dewasa lebih pendek daripada kambing muda. 


\section{DAFTAR PUSTAKA}

Isroli, Santoso SAB, Haryati N. 2004. Respon termoregulasi dan kadar urea darah domba garut betina yang dipelihara di dataran tinggi terhadap pencukuran wool. J Pengembangan Peternakan Tropis. 2:126-131.

Karnadi J. 1999. Stres dalam kehidupan sehari-hari. Cermin Dunia Kedokteran. 123:20.

Lasmi I. 1988. Analisis transportasi sapi potong dari daerah tingkat II Kabupaten Lamongan ke DKI Jakarta (Skripsi). [Bogor (Indonesia)]: Institut Pertanian Bogor.

Nelvita T, Purnomoadi A, Rianto E. 2018. Pemulihan kondisi fisiologis, konsumsi pakan dan bobot badan domba ekor tipis pada umur muda dan dewasa pasca transportasi pada siang hari. J Sains Peternakan Indonesia. 13:337-342.

Pambudi RA. 2017. Perbandingan denyut nadi, frekuensi nafas dan suhu rektal anak kambing lokal pra-sapih pada tipe kelahiran tunggal dan kembar (Skripsi). [Semarang (Indonesia)]: Universitas Diponegoro.

Pramono D, Maryanto, Asih D. 2005. Sumber hayati ternak lokal Jawa Tengah. Semarang (Indonesia): Dinas Peternakan Provinsi Jawa Tengah.

Puspitasari AL. 2016. Pengaruh Naungan saat transportasi terhadap perubahan dan lama pemulihan fisiologi kambing kacang (Skripsi). [Semarang (Indonesia)]: Universitas Diponegoro.

Ramadhan AF, Dartosukarno S, Purnomoadi A. 2017. Pengaruh pemberian vitamin komplek terhadap pemulihan fisiologis, konsumsi dan bobot badan kambing kacang pasca transportasi. Mediagro. 13:23-33.

Santosa U, Tanuwiria UH, Yulianti A, Suryadi U. 2012. Pemanfaatan kromium organik limbah penyamakan kulit untuk mengurangi stres transportasi dan memperpendek periode pemulihan pada sapi potong. JITV. 17:218-224.

Selye H. 1976. Forty years of stress research: principal remaining problems and misconceptions. J Can Med Assoc. 115:53-56.

Setyawan ANB. 2013. Pengaruh transportasi terhadap penyusutan dan pemulihan kondisi pada kambing kacang dengan bobot badan yang berbeda (Skripsi). [Semarang (Indonesia)]: Universitas Diponegoro.

Sodiq A. 2009. Karakteristik sumberdaya kambing lokal khas Kejobong di Kabupaten Purbalingga Provinsi Jawa-Tengah. J Agripet. 9:31-37.

Steel RGD, Torrie JH. 1993. Prinsip dan prosedur statistika. Sumantri B, penerjemah. Jakarta (Indonesia): Gramedia, Jakarta.

Suherman D, Purwanto BP, Manalu W, Permana IG. 2013. Simulasi artificial neural network untuk menentukan suhu kritis pada sapi Fries Holland berdasarkan respon fisiologis. JITV. 18:70-80.

Suwignyo B, Wijaya UA, Indriani R, Kurniawati A, Widiyono I, Sarmin. 2016. Konsumsi, kecernaan nutrien, perubahan berat badan dan status fisiologis kambing bligon jantan dengan pembatasan pakan. J Sain Veteriner. 34:210-219.

Wuryanto IPR, Darmoatmodjo LMYD, Dartosukarno S, Arifin M, Purnomoadi A. 2010. Produktivitas, respon fisiologis dan perubahan komposisi tubuh sapi Jawa yang diberi pakan dengan tingkat protein berbeda. Prosiding Seminar Nasional Teknologi Peternakan dan Veteriner. Bogor (Indonesia): Pusat Penelitian dan Pengembangan Peternakan. hlm. 331-338. 